\title{
A New Approach to Mapping Granites
}

\author{
by E. John Cobbing and Donald I.J. Mallick
}

\begin{abstract}
Recent geological work in the Peruvian Andes has led to many new ideas and discoveries on the Coastal Batholith and its component intrusions. New approaches developed in this area for the mapping and subdivision of batholithic regions are now being tested in a regional granite project in Southeast Asia. The authors describe these results and discuss their general applicability else where.
\end{abstract}

\begin{abstract}
A Regional Approach Emerges from Work in Peru
Until the 1960s most of the world's large batholithic granite masses were shown on maps as uniform red blobs, although descriptions of these masses made it clear they were made up of different components distinguishable by their various textures, compositions or both. In most cases the spatial distribution and three-dimensional form of these components was understood only in very general terms, despite the association of many metalliferous ore deposits with granitoid bodies of one sort or another.
\end{abstract}

Such considerations provided the background to a major research project on the Coastal Batholith of Peru between 1965 and 1980. This was undertaken by geologists from the U.K. Institute of Geological Sciences (IGS) and Liverpool University with support from the Overseas Development Administration (ODA), the Natural Environment Research Council of the U.K. and the Instituto de Geologia, Mineria y Metallurgia del Peru. The study was envisaged from the start as progressing in two stages which would be mutually supportive. Fieldwork would establish the size, shape and field relationships of individual granitic plutons, and these results would be used as a basis for geochemical and geochronological studies.

It was quickly found that because of the excellent outcrop (Fig. 1) in the mountainous desert terrain of the western Andes it was possible with the aid of air photos (Fig. 2) to map large areas very quickly, not perhaps in the detail attained by studies in Europe, but sufficient to establish the essential geological relationships of the various granite bodies over an area $60 \mathrm{~km}$ by $100 \mathrm{~km}$. This led to the realization that there are relationships between the granite plutons which had not formerly been suspected. In fact the Andean Batholith is such a vast structure that it is necessary to consider a large portion of it in order to be able to appreciate any pattern at all.

The mapping of the batholith was therefore continued in earnest and, in the course of the next 15 years, a total of 45 quarter degree quadrangles (totalling $135000 \mathrm{~km}^{2}$ ) at a scale of 1:100000 were completed and about a dozen more revised. The final result was a complete map (see Fig. 3) of the batholith and its surrounding rocks over a strike length of $1500 \mathrm{~km}$ (Cobbing et al., 1981 and in preparation). The laboratory work has confirmed the basic insights derived from the fieldwork, and the geochemical studies continue.

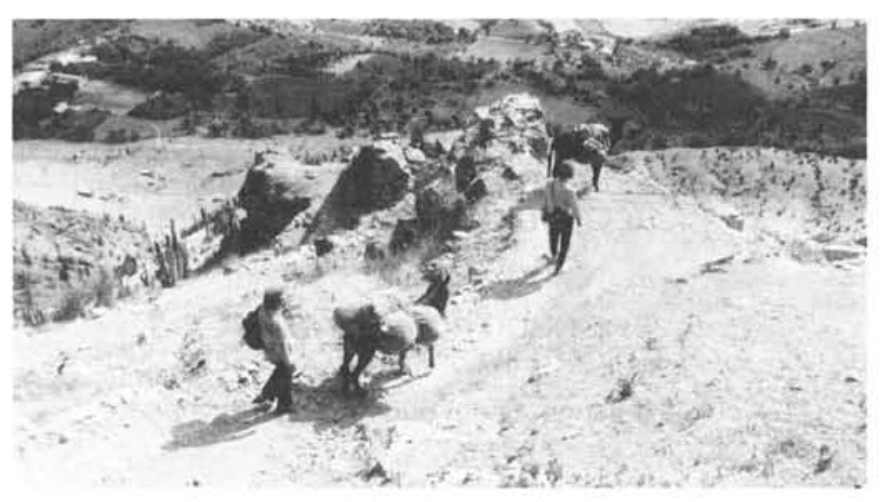

Figure 1: Donkeys carrying field equipment in the Coastal Batholith about $100 \mathrm{~km}$ south of Lima, Peru.

The main conclusions are that the Andean Batholith was generated by processes related to the subduction of oceanic lithosphere beneath the continental margin, and that the numerous intrusions of which it is made up are organized quite systematically into chains of plutons. Each pluton within a single chain is of similar petrographic character to all the others, and each chain is distinguished by its own special petrography. The rocks of any one particular chain show a range of composition (commonly from diorite to monzogranite) and are referred to as constituting a granite super-unit (Pitcher, 1978; Cobbing et al., 1977) with each main lithology comprising a unit (Fig. 3 ).

The chains of plutons interfere structurally with one another, and a regional sequence can be distinguished by observation of the intrusive relationships. Each super-unit or unit occupies a particular position in the intrusive sequence and so is comparable in status to a stratigraphic formation, having distinctive lithological (particularly textural), structural and temporal characteristics. Within a super-unit the diorites and tonalites are generally earlier than the acid rocks, but basic constituents of a later super-unit will post-date acid elements of an earlier one.

As well as being organized into super-units, the Andean Coastal Batholith can be divided on an even larger scale into batholithic segments grouping together several super-units (Fig. 3). Both granite super-units and batholithic segments 


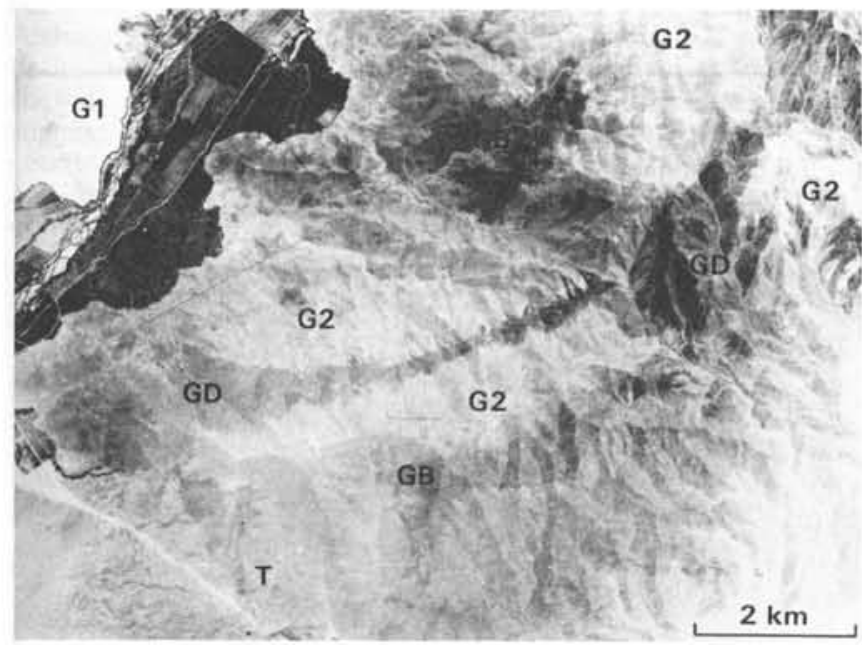

Figure 2: Air photo of the Huaura ring complex Peru. G1, G2 - different granites; GD - granodiorite; $T$ - tonalite with a dyke swarm; GB - gabbro.

are very large structures which range from about 100 to 1000 $\mathrm{km}$ in length. There are differences in the degree of mineralization, both between super-units and between segments. The economic porphyry copper deposits of southern Peru, for example, occur largely within the Yarabamba Unit (mainly monzogranite) of the Toquepala segment, whereas porphyry copper deposits in other segments are largely subeconomic. Thus, the granitoid intrusions in this tectonic setting exhibit a regular pattern of generation and emplacement which, once identified, makes their recognition and study a relatively easy matter.

For those of us fortunate enough to have been involved in the Peruvian project the experience was very illuminating. On the one hand there were many single plutons that detailed study revealed to be of great complexity, while on the other hand the granitoid super-unit of which the pluton was a part, was a relatively simple element of the batholith as a whole and could be understood in terms of the regional framework. Clearly a balance had to be struck between regional and detailed studies. In this type of well-exposed terrain with excellent air photo cover and reasonable access, the result was a mixture of regional reconnaissance mapping and detailed investigations of particular plutons.

The Peruvian experience indicated that the proper way to tackle the granites of orogenic belts was in a regional manner. The more normal piecemeal approach whereby isolated plutons are studied in great detail does not allow the information to be readily integrated at the proper scale, that for the whole orogen or a considerable part of it. Similar conclusions were, of course, reached earlier about the cordilleran granites of southwest U.S.A. (Larsen, 1948; Bateman and Dodge, 1970).

What then of the other types of granites that occur in large quantities, such as the granite belts with which tin mineralization is associated, or the "gregarious" batholiths of the Precambrian shields? Do they comprise assemblages of granite units similar to those of the cordilleran batholiths? And is it possible within an acceptable framework dictated by time and money to study such granite bodies on a regional basis in temperate and tropical environments with much more limited exposures?

\section{Application to SE Asia}

To attempt to answer some of these questions, a regional study of the voluminous granites of the SE Asian tin belt began in 1981, involving IGS and the Geological Surveys of Malaysia, Indonesia and Thailand. These granites are differ- ent in several ways from the Peruvian and other CircumPacific granites that are associated with copper and base metal mineralization.

For simplicity, granitoid super-units and units will henceforth be referred to informally as granite units. This also has the merit of permitting the classification of granites from other orogenic belts according to patterns of local or regional significance, which do not necessarily conform to those established in Peru.

The SE Asian granites are normally very acid S-type granites or granodiorites with high initial ${ }^{87} \mathrm{Sr} /{ }^{86} \mathrm{Sr}$ ratios $(>0.710)$ suggesting an origin involving crustal anatexis (Chappell and White, 1974). They are generally located in orogenic belts where the tectonic regime is not well understood or is hotly debated. In contrast, the Circum-Pacific I-type granitoids of Peru and elsewhere are typically tonalites and granodiorites, with a range from gabbro to granite. They have low initial ${ }^{87} \mathrm{Sr} /{ }^{86} \mathrm{Sr}$ ratios $(<0.706)$ suggesting a mantle derivation (Chappell and White, 1974), and they are commonly an essential part of orogenic belts that can be related to the subduction of oceanic crust beneath continental margins.

Despite these contrasts, there was a basic expectation that the batholiths of SE Asia, like those of Peru, would be made up of many individual plutons. The main questions were whether these could be mapped adequately in the jungle terrain of that area and whether they would map out as granite units. Of course, not all S-type granites are stan-

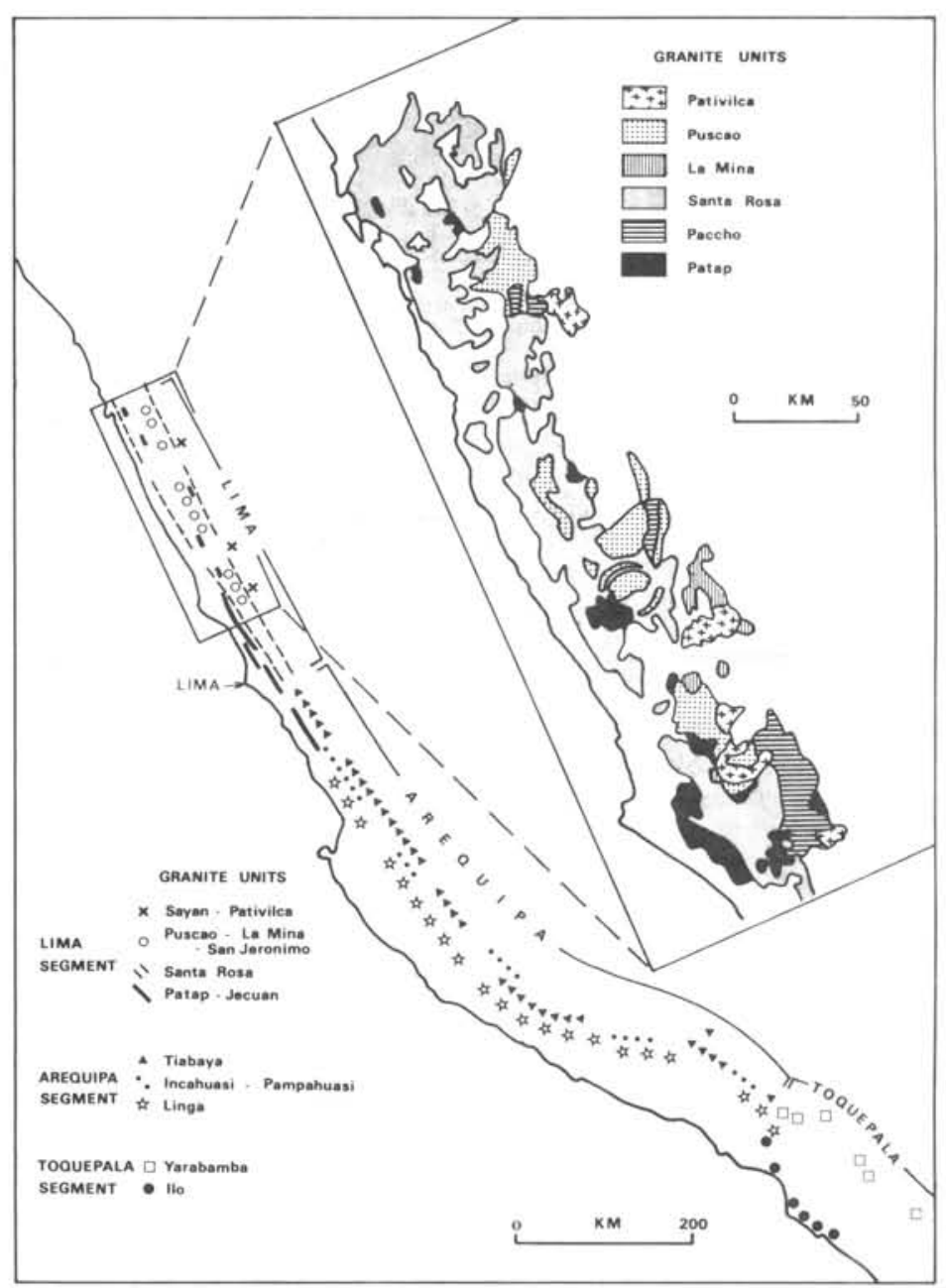

Figure 3: Granite units and batholithic segments of the Peruvian Coastal Batholith. Inset map shows details of the Lima segment. 


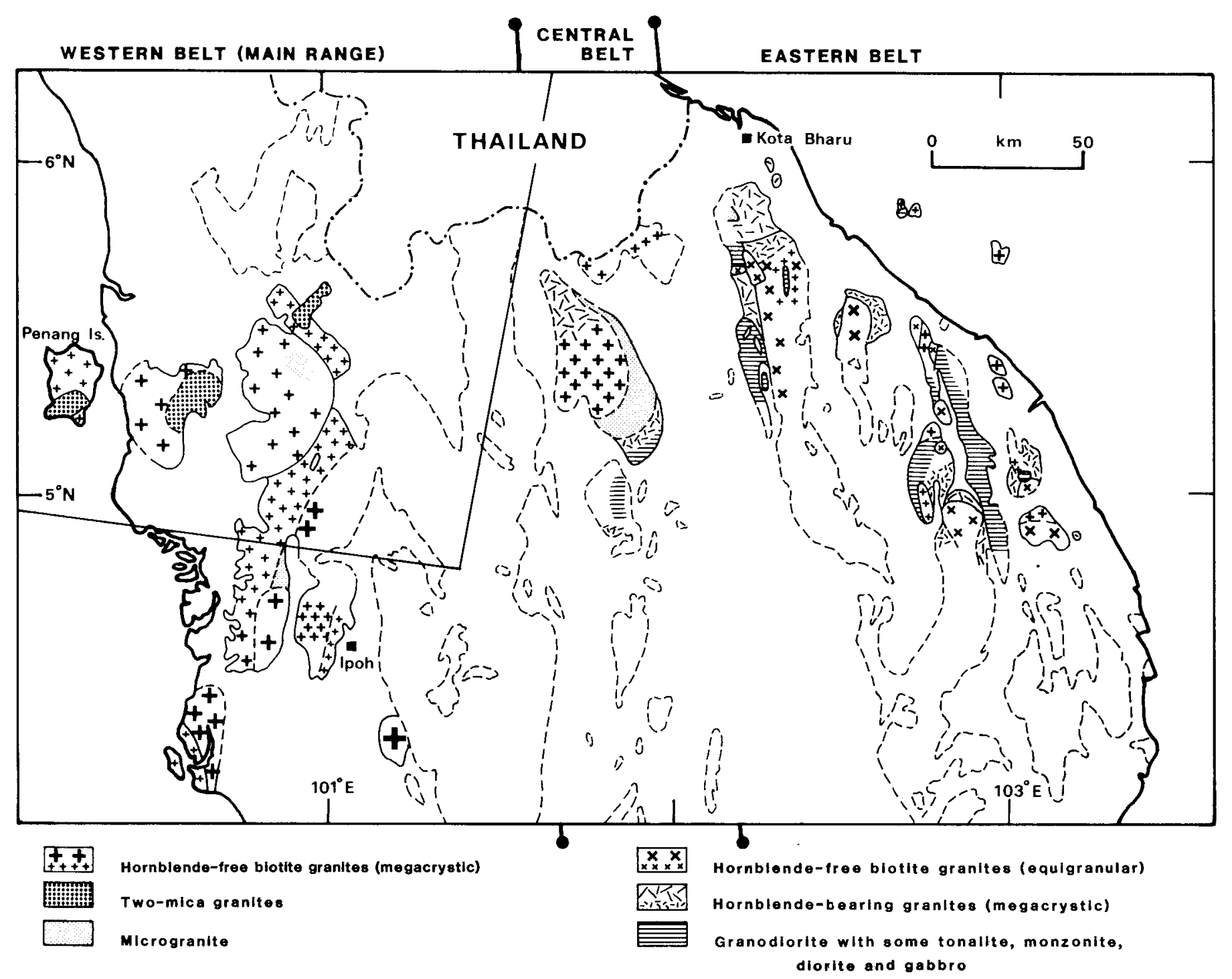

Figure 4: Sketch map of the granite bodies of northern Malaysia. Undifferentiated granites left blank. Inset: area shown in Figure 5.

niferous, and it has been known for some time that tin is associated only with certain phases of a granite suite, particularly some of the pegmatites and microgranites. Thus in order to understand the distribution of tin within such a granitic terrain, it is essential to first establish the distribution and mutual relations of the various component plutons as a sound basis for detailed mineralogical and geochemical studies.

Peninsular Malaysia was chosen for the first, experimental part of the project (Fig. 4). The granites here are particularly abundant, forming $30 \%$ of the surface area, and are disposed in two major granite belts, the Western Belt, or Main Range Batholith, and the Eastern Belt (Hutchison, 1977). A third, less voluminous Central Belt is largely tinfree and characterized by gold and base metal mineralization; petrologically it has clear affinities with the Eastern Belt. Most of the Main Range granites are gathered into one enormous batholith, formed mainly of biotite and two-mica granites which are the source rocks for widespread deposits of alluvial tin. The granitoid rocks of the Eastern Belt are more widely dispersed in smaller, more complex batholiths and plutons that range in composition from gabbro to granite. While these resemble in some ways the I-type granites of Peru (Table 1), they are also associated with tin deposits and are similar in several ways to S-type granites.
Field parties were assigned to the two Malaysian belts with a view to establishing whether their component plutons could be successfully identified and mapped, and the results would then be extrapolated to other parts of the orogen in Thailand and Indonesia. The exploratory field work in Malaysia proved successful in this respect (Fig. 4), and the project has now (1983) been extended to Indonesia. Follow-up studies are now underway involving geochemistry and geochronology.

There are, of course, major differences between regional granite studies in Peru and Malaysia, related primarily to the quality of exposure. Whereas in Peru it is possible to construct a good photogeological map showing the distribution and geometry of most of the plutons, this is not the case in SE Asia. However, even here aerial photographs and satellite images (Fig. 5) indicate fairly accurately the location of granitic areas, and contacts between granite plutons and the surrounding country rocks may be quite well defined. However, unlike Peru, the discrimination by remote sensing of separate plutons within a batholith is generally not possible in SE Asia, because of the very limited lithological contrast between plutons, the dense rain forest and thick soil cover. Nevertheless shuttle radar (SIR-A) does permit some subdivision of the nor theast Malaysian batholith.

In SE Asia, the most useful guides to regional granite mapping are the existing geological maps, most of which have 
been made at the cost of enormous labour over many years. Although these maps do not usually distinguish plutons within batholiths, the outline of the batholith against the country rock is carefully drawn, and where this is lobate it may suggest the shape of an individual interior pluton. Rafts of country rock within the batholiths are also accurately shown, and these quite often turn out to be screens located at contacts between plutons.

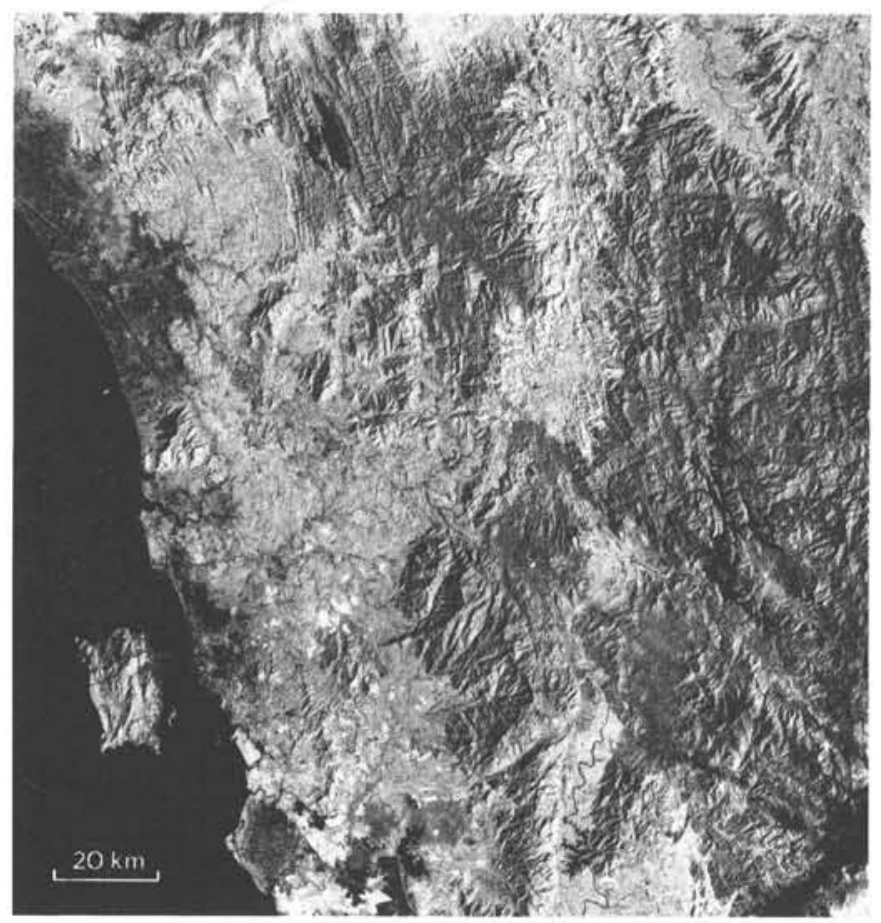

Figure 5: NASA Landsat view of NW Malaysia.

Our method here is to make maximum use of roads and to assess as many drainage basins as possible by examining the granite boulders in the stream beds. Although this is a highly reconnaissance method, with care and experience it can be effective. We have tended to avoid long jungle traverses except where absolutely necessary, because an average speed of three miles a day is too slow for our time frame.

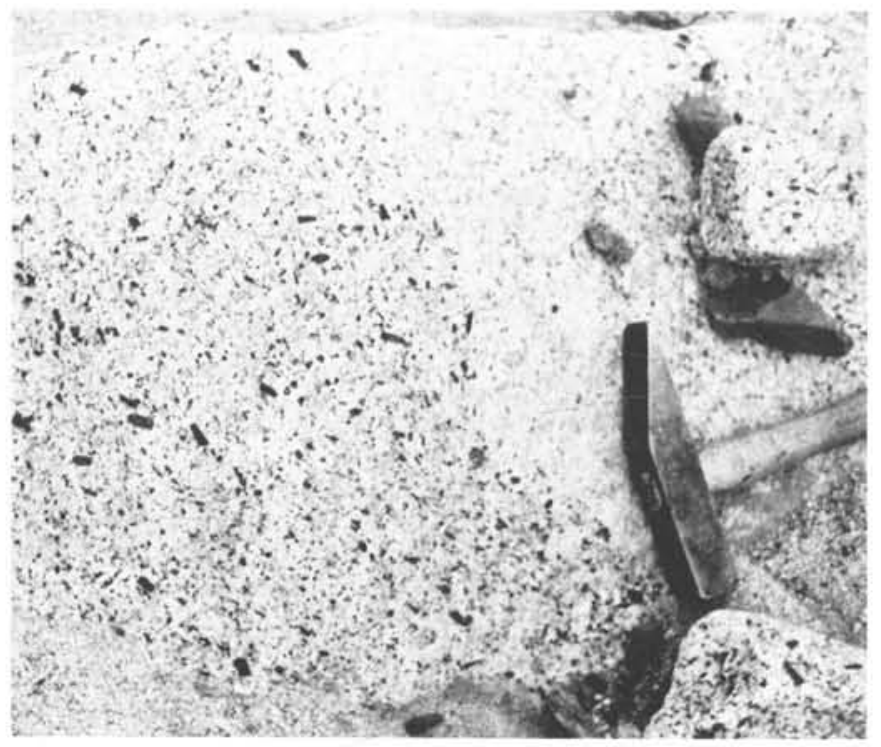

Figure 6: Lithology of a Peruvian granodiorite from the Tiabaya super-unit, showing large hornblendes.

\section{Granite Texture - The Key}

All the lithological and textural varieties within a granite pluton have an underlying textural unity. The human eye is actually very good at detecting and integrating such features, and most geological fieldwork utilizes this facility.

One of the major insights of the Peruvian work was that rock textures were very specific both for individual plutons and for granite units. For example, in the Tiabaya granite unit (Fig. 3) the hornblende occurs as widely spaced prismatic euhedral crystals and the biotite forms isolated well-shaped books (Fig. 6), whereas in the Santa Rosa granite unit both the hornblende and biotite are aggregated in shapeless clots. Textural differences of these and other kinds serve to characterize granite units with similar compositional ranges, perhaps from diorite to monzogranite. Thus in Peru rock texture rather than rock composition was our most useful mapping criterion.

So as to identify in a systematic way the diagnostic textural features of plutons and/or granite units in SE Asia, a collecting sheet (Fig. 7) was designed for recording textural and mineralogical information, and after a good deal of trial and error this sheet is approaching its final format. In the course of the project so far, we have found its use to be of great benefit: it has the advantage of unifying descriptive procedures in a multinational project. This field sheet forces the field worker to look for, identify and describe each mineral one by one, and the result is a much more careful appraisal of the granite lithology than is customary.

Unlike Peru, where variations in the mafic constituents dominate the texture, in South East Asia the salic minerals are of greater importance, although some of the Eastern Belt granitoids are characterized by the nature of their mafics. The size, shape, abundance, spacing and distribution of potash feldspar megacrysts have proved to be critical factors, particularly in the Western Belt (Fig. 8). Here we have found that the textures developed within a single pluton are usually sufficiently distinctive to differentiate it from every other pluton that we have examined. Nearly every granite unit is thus defined by a single pluton, not a chain.

In the Eastern Belt most plutons are likewise distinctive granite units, though in some cases there are petrographic similarities between plutons belonging to one or more batholiths. However, neither the scale of development nor the range of lithologies present is analogous to that seen in Peru. Thus, multi-pluton granite units as in the Andes are the

\begin{tabular}{|c|c|c|c|}
\hline \multicolumn{4}{|c|}{$\begin{array}{r}\text { Table } 1 \\
\text { Comparison of Some Features of the Gran } \\
\text { MALAYSIA }\end{array}$} \\
\hline & $\begin{array}{l}\text { Western Belt } \\
\text { Granites }\end{array}$ & $\begin{array}{c}\text { Eastern Belt } \\
\text { Granites }\end{array}$ & PERU \\
\hline $\begin{array}{l}\text { Range of } \\
\text { lithology }\end{array}$ & $\begin{array}{l}\text { granite - } \\
\text { granodiorite }\end{array}$ & granite - gabbro & granite - gabbro \\
\hline $\begin{array}{l}\text { Predominant } \\
\text { lithology }\end{array}$ & granite & granite & tonalite \\
\hline $\begin{array}{l}\text { Textural } \\
\text { variation }\end{array}$ & $\begin{array}{l}\text { wide range within } \\
\text { each rock unit }\end{array}$ & $\begin{array}{l}\text { narrow range within } \\
\text { each rock unit }\end{array}$ & $\begin{array}{l}\text { narrow range within } \\
\text { each rock unit }\end{array}$ \\
\hline Hornblende & absent & commonly present & always present \\
\hline Muscovite & $\begin{array}{l}\text { abundant in some } \\
\text { rocks }\end{array}$ & very rare & absent \\
\hline $\begin{array}{l}\text { Average or range } \\
\text { of pluton size }\end{array}$ & $40 \times 10 \mathrm{~km}$ & $15 \times 15 \mathrm{~km}$ & $\begin{array}{l}70 \times 35 \mathrm{~km} \text { to } \\
5 \times 5 \mathrm{~km}\end{array}$ \\
\hline Type of pluton & $\begin{array}{l}\text { complex, commonly } \\
\text { with metasomatic } \\
\text { overprint }\end{array}$ & simple & complex and simple \\
\hline $\begin{array}{l}\text { Type of } \\
\text { batholith }\end{array}$ & $\begin{array}{l}\text { aggregate of large } \\
\text { complex plutons }\end{array}$ & $\begin{array}{l}\text { aggregate of small } \\
\text { simple plutons }\end{array}$ & $\begin{array}{l}\text { aggregate of large } \\
\text { and small complex } \\
\text { and simple plutons }\end{array}$ \\
\hline $\begin{array}{l}\text { Granite type in } \\
\text { repeated plutons } \\
\text { or unique for } \\
\text { each pluton }\end{array}$ & unique & unique & repeated plutons \\
\hline
\end{tabular}


Collector

Date

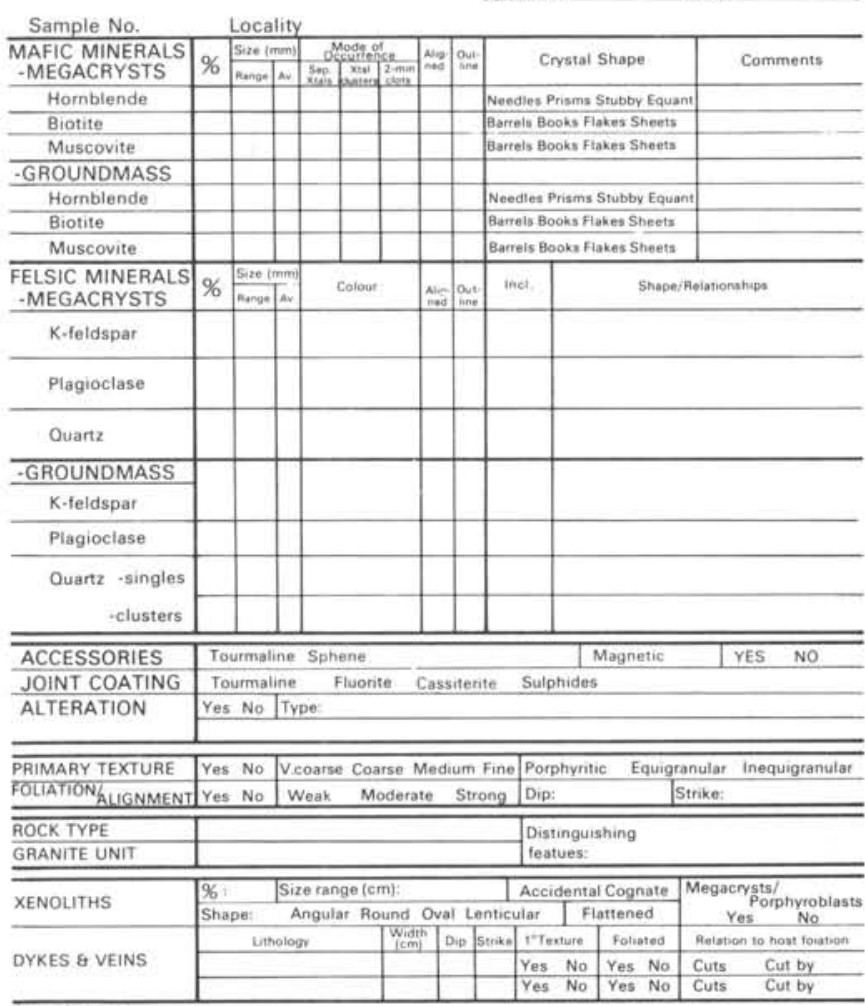

REMARKS :

Figure 7: Granite data recording sheet.

exception rather than the rule in SE Asia, where most batholiths consist of clusters of unique plutons. The implication is that these magmas were generated locally in small batches and under different conditions, in contrast to Peru where identical magmas were produced under the same PT and environmental conditions prevailing over great lengths of the Andean region.

The mineralogical differences between the granites of the Main Range and those of the Eastern Belt of Malaysia recorded by Hutchison (1977) are accompanied by differences in the size, shape and distribution of the granite bodies (Table 1). Available geochronological data (Bignell and Snelling, 1977) suggest that the granites of the two belts overlap at least partly in age; the interpretation of these differences is thus not easy.

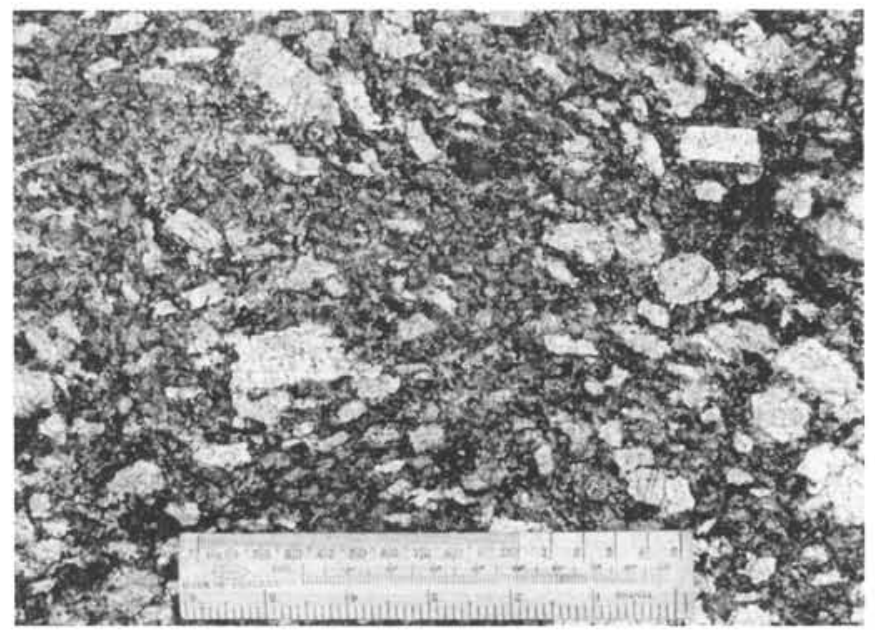

Figure 8: Potash feldspar megacrysts in the Taiping Granite of the Main Range.
The recent work in Peru and Malaysia should stimulate more regional granite studies, leading to a much better understanding of deep crustal processes because of the widespread association of granites with orogenic belts. We believe the methods outlined above can also be applied successfully to earlier orogens. Although it is to be expected that the granites of each fold belt are likely to show individual peculiarities, the method is sufficiently flexible to permit the recognition and integration of these differences within a regional framework. Plate tectonics provides a working hypothesis that can serve as a starting point for regional work of this kind. If such regional studies were undertaken on a sufficiently wide scale, in one or two decades the granites of the world might not be the enigmatic objects they are at present.

\section{Acknowledgements}

The funding for the work in Malaysia is being provided by the United Kingdom Overseas Development Administration and by the Geological Survey of Malaysia. This paper is published by permission of the Directors, Institute of Geological Sciences (N.E.R.C.) and of the Geological Survey of Malaysia.

\section{ABOUT THE AUTHORS:}

Dr. E. John Cobbing is Senior Principal Scientific Officer in the Overseas Division of the Institute of Geological Sciences, (Keyworth, Nottingham NG12 5GG, U.K.) with special interest in granites. He worked extensively on the Coastal Batholith of Peru and is U.K. National Correspondent for IGCP Project No. 120 , 'Magmatic Evolution of the Andes'.

Dr. Donald I.J. Mallick is a Principal Scientific Officer in the IGS Overseas Division with special interest in granites and in remote sensing. He is the U.K. national representative for the European Association of Remote Sensing Laboratories.
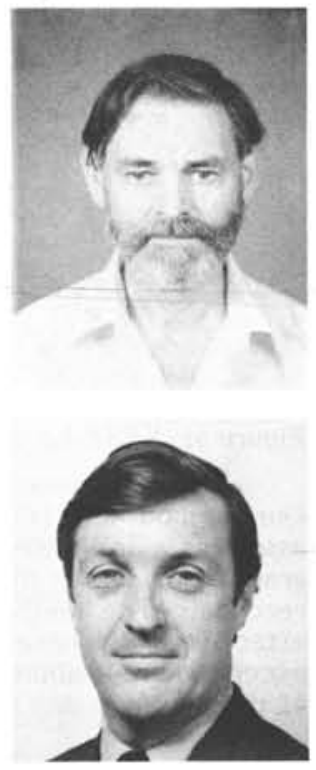

\section{References}

Bateman, P.C. and Dodge, F.C.W., 1970. Variations of major chemical constituents across the central Sierra Nevada batholith. Bulletin of the Geological Society of America, v. 81, p. 409-420.

Bignell, J.D. and Snelling, N.J., 1977. The geochronology of the Malayan Granites. Overseas Geology and Mineral Resources, No. 47, 70 pp.

Chappell, B.W. and White, A.J.R., 1974. Two contrasting granite types. Pacific Geology, v. 8, p. 173-174.

Cobbing, E.J., Pitcher, W.S. and Taylor, W.P., 1977. Segments and Super-units in the Coastal Batholith of Peru. Journal of Geology, v. 85 , p. 625-631.

Cobbing, E.J., Pitcher, W.S., Wilson, J.J., Baldock, J.W., Taylor, W.P., McCourt, W.J. and Snelling, N.J., 1981. The geology of the Western Cordillera of northern Peru. Overseas Memoirs, Institute of Geological Sciences, no. 5, $143 \mathrm{p}$.

Hutchison, C.S., 1977. Granite emplacement and tectonic subdivision of Peninsular Malaysia. Geological Society of Malaysia Bulletin 9, p. 187-207.

Larsen, E.S., 1948. Batholith and associated rocks of Corona, Elsinore and San Luis Rey quadrangles, southern California. Memoirs of the Geological Society of America, no. 29, 182p.

Pitcher, W.S., 1978. The anatomy of a batholith. Journal of the Geological Society of London, v. 135, p. 157-182. 